\title{
A preliminary engineering geological study in the northern part of the Taplejung Window, far eastern Lesser Nepal Himalaya
}

\author{
*T. P. Gautam ${ }^{1}$, D. R. Sonyok ${ }^{2}$, B. N. Upreti ${ }^{3}$, S. M. Rai ${ }^{3}$, and H. Sakai ${ }^{4}$ \\ 'Institute of Environmental Studies, The University of Tokyo, Bunkyo-Ku, Tokyo 113-8656, Japan \\ ${ }^{2}$ Department of Civil and Structural Engineering, Kyushu University, 6-10-1 Hakozaki, Fukuoka, Japan \\ ${ }^{3}$ Department of Geology, Tribhuvan University, Tri-Chandra Campus, Ghantaghar, Kathmandu, Nepal \\ ${ }^{4}$ Department of Earth Sciences, Kyushu University, Ropponmatsu, Fukuoka 810-8560, Japan \\ (*E-mail:tpgautam@gmail.com)
}

\begin{abstract}
In the northern part of the Taplejung area, two tectonic units are recognised. These are the Higher Himalayan and Lesser Himalayan Sequences separated by the Main Central Thrust (MCT). The Lesser Himalayan Sequence is exposed in the Taplejung Window represented by Taplejung Formation, Mitlung Augen Gneiss, and Lingkhim Schist from the bottom to top. The main rock types in the Lesser Himalayan Sequence are phyllite, schist, metasandstone, quartzite and augen gneiss. Three Proterozoic granitic bodies are intruded into Taplejung Formation: Tamor River Granite, Amarpur Granite and Kabeli Khola Granite. The rocks of the Higher Himalaya on the hanging wall of the MCT are composed of kyanite-sillimanite bearing banded gneiss, orthogneiss, migmatite, quartzite.

Three major landslides in the area, viz., Hangdewa, Hireba, and Paire lie along the valley slope sides of the Tamor River. Stream erosion and incision, presence of highly weathered rocks, surface and subsurface drainage are responsible in activating the landslides. Due to the presence of mainly weathered phyllites, favourable structural orientations and wet cultivation practice in the area have contributed to the development of these landslides. The Hangdewa and Hireba landslides have endangered the villages in between them and ultimately the Suketar airport. The landslides are gradually destroying more and more areas of cultivated land and property and increased loss of human lives.

Excessive anthropogenic interference in the form of development activities like unplanned urbanization, deforestation and unfavorable agricultural practices have greatly aggravated the situation. The intensity of damages amplifies during the late part of monsoon each year. The study suggests that further detailed surface and subsurface investigation of the landslides are needed to prevent further loss of lives and property.
\end{abstract}

\section{INTRODUCTION}

The study area lies in the Taplejung District of far eastern Nepal Himalaya (Fig.1). The mountain belt of Nepal experiences one of the highest rates of erosion in the world. Many large and small-scale mass wasting phenomena such as landslide, slope failure, erosion etc. is very common in Nepal. The steep hill slopes and heavy monsoon precipitation favour to the mass-wasting phenomenon in the area.

The geology of the Taplejung Window comprises rocks of Lesser Himalayan Sequence. The Lesser Himalayan Sequence is thrust over by the rocks of Higher Himalaya along the Main Central Thrust (MCT). During the monsoon of 2002, heavy rainfall triggered many old and new landslides. The major landslides have caused losses of many human lives and large amount of properties every year. The Hangdewa, Hireba and Paire landslides are major landslides in the area. These landslides are reactivated old landslides and driven by complex failure mechanism. It is also observed that the residual and colluvial soil of the north facing slopes are also contributing to the slope failures. These landslides feed a large amount of debris annually into the Tamor River.
The main objectives of this study were to carry out geological mapping, identification of landslide characteristics, and to prepare an engineering geological map of the Mechi Highway between Sesambu to Mewaraja villages.

\section{GEOLOGICAL SETTING}

The study area is comprised of the metasediments of the Lesser Himalayan Sequence (LHS) overthrust by the highgrade metamorphic rocks of the Higher Himalaya along the Main Central Thrust (MCT). The Lesser Himalayan rocks are represented mainly by metasedimentary rocks such as phyllites with interbedded quartzites, schists and augen gneisses (Schelling and Arita 1991; Schelling 1992; Upreti et al. 2000, 2003; Rai et al. 2001, 2004). The successive units of the Lesser Himalayan Sequence consist of Taplejung Formation, Mitlung Augen Gneiss, and Lingkhim Schist from bottom to top (Gautam 2001, Sonyok 2001, Upreti et al. 2003) (Fig 2).

The lower part of the Lesser Himalayan Sequences is represented by the Taplejung Formation (Schelling and Arita 


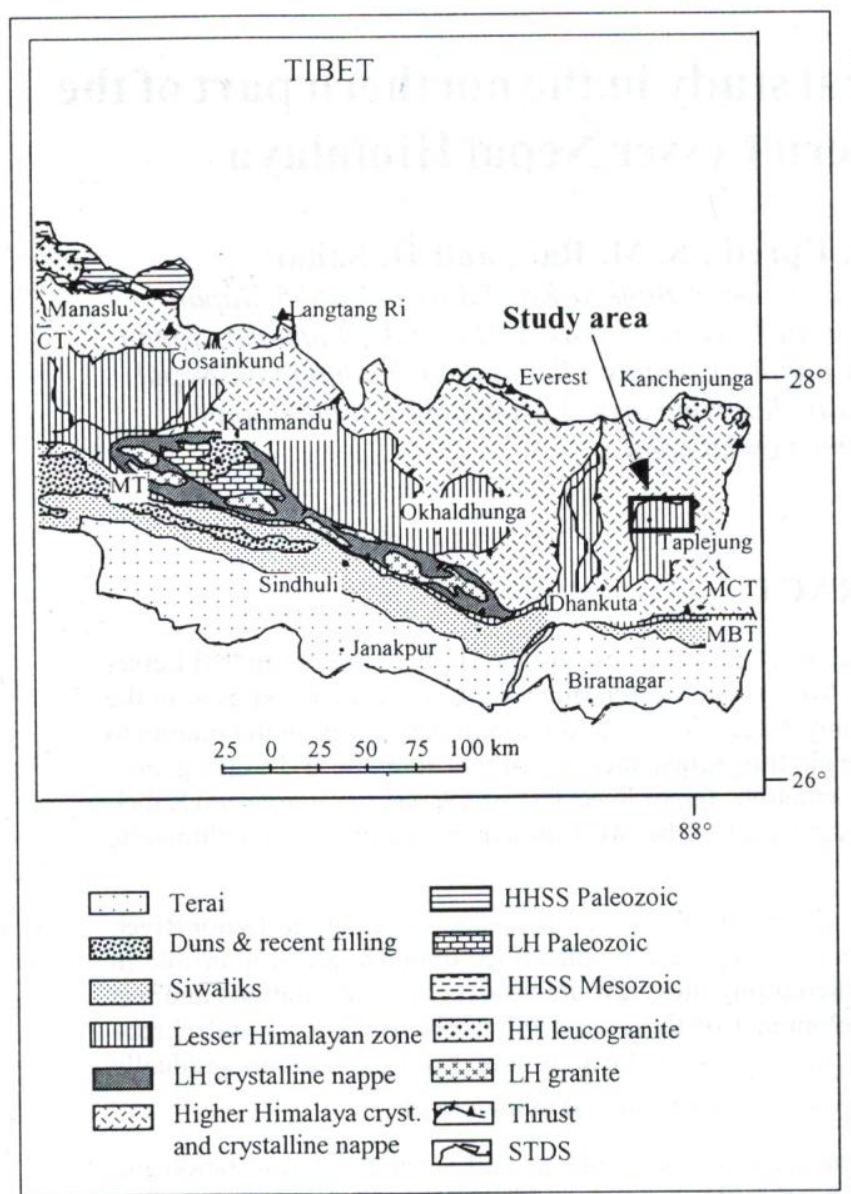

Fig. 1: Geological map of Nepal (after Upreti and Le Fort 1999) with location of study area. HH leucogranite: Higher Himalayan leucogranite, HHSS Mesozoic: Tethyan Sedimentary Series (Mesozoic) of the Higher Himalaya, HHSS Paleozoic: Tethyan Sedimentary Series (Paleozoic) of the Higher Himalaya, LH crystalline nappe: Lesser Himalayan crystalline nappe, LH granite: "Lesser Himalayan" granite, LH Paleozoic: Sedimentary Series (Paleozoic) of the Lesser Himalayan nappes (Phulchauki Group), MBT: Main Boundary Thrust, MCT: Main Central Thrust, MT: Mahabharat Thrust, STDS: South Tibetan Detachment System.

1991; Schelling 1992; Upreti et al. 2003). It is mainly composed of chloritic to sericitic, thinly to thickly foliated, light gray to dark gray-greenish colored phyllite with interbeds of quartzite and metasandstone. Tiny crystals of garnet are present on the top of this section. Three granitic bodies: Kabeli Khola Granite, Amarpur Granite and Tamor River Granite intrude into Taplejung Formation (Upreti et al. 2003). The granitic body exhibits foliation and gneissic texture towards its margins while the core part shows the porphyritic and occasionally equigranular texture. The lithological correlation of this formation can be made with the rocks of the Kuncha Formation of central Nepal (Bordet 1961, Stocklin 1980). Mitlung Augen Gneiss overlies the Taplejung Formation and consists of strongly deformed two-mica gneiss with predominant augens of quartz and feldspar. The S-C structure is commonly observed in this formation showing the top to south sense of shear. The Lingkhim Schist is the uppermost unit of the Lesser Himalayan Sequence of the Taplejung Window and it is characterized by strongly foliated metapelitic biotite schists with or without garnets. Intercalation of quartzite is also present in the area.

The Higher Himalayan Sequence is exposed in the northern part of the study area. It is composed of kyanite and sillimanite bearing banded gneiss, orthogneiss, and migmatite at the lower section. This tectonic unit is equivalent to the Formation I of the Higher Himalaya of central and western Nepal (Le Fort 1975).

\section{LANDSLIDE DISTRIBUTIION}

A number of active and old landslides are mapped in the watersheds of Hangdewa-Hireba, Dokhu-Nangkholyang and Hangpang-Phulbari village areas. The debris of these landslides drain out into the Tamor River. Soil erosion is very common on the slopes. In many ways, soil erosion has enhanced mass movements and incision of gullies. The high intensity rainfall in the area is also a contributing factor for mass movement. In the study area, there are ten active and five old landslides. Hangdewa, Hireba, and Paire are the major landslides. Most of the landslides are located on the slopes of Tamor River valley.

In this study the landslide classification system proposed by Cruden and Varnes (1996) is followed to describe different types of mass movements. Most of the individual mass movements represent complex and composite type of landslides, derived mainly from rotational slide at its beginning.

\section{Hangdewa landslide}

The Hangdewa landslide is the most active, largest and hazardous landslide in the region. Most of the villages in the area are severely affected by this landslide. The crown of the landslide has reached up to the ridge near Suketar airport. It is likely that the landslide will ultimately affect the airport. The ridge separates two hill slopes into northern and southern watersheds namely Hangdewa-Hireba and Dokhu-Nangkholyang respectively.

Hangdewa landslide was initiated more than 100 years ago. The Hangdewa Khola flows centrally through the landslide. Although the landslides are distributed on both banks of the Hangdewa Khola, the left bank of the valley is severely affected and top part shows rotational slides (Fig. 3). The mass-movement is frequent along the small tributaries and subsequently on their valley sides.

The Hangdewa landslide covers an area of about $10 \mathrm{sq}$ $\mathrm{km}$ with a maximum length of $5 \mathrm{~km}$ and the width of $2 \mathrm{~km}$. The active part of the landslide is reported in the middle part of the hill slope and southeast portion of Hangdewa village. 


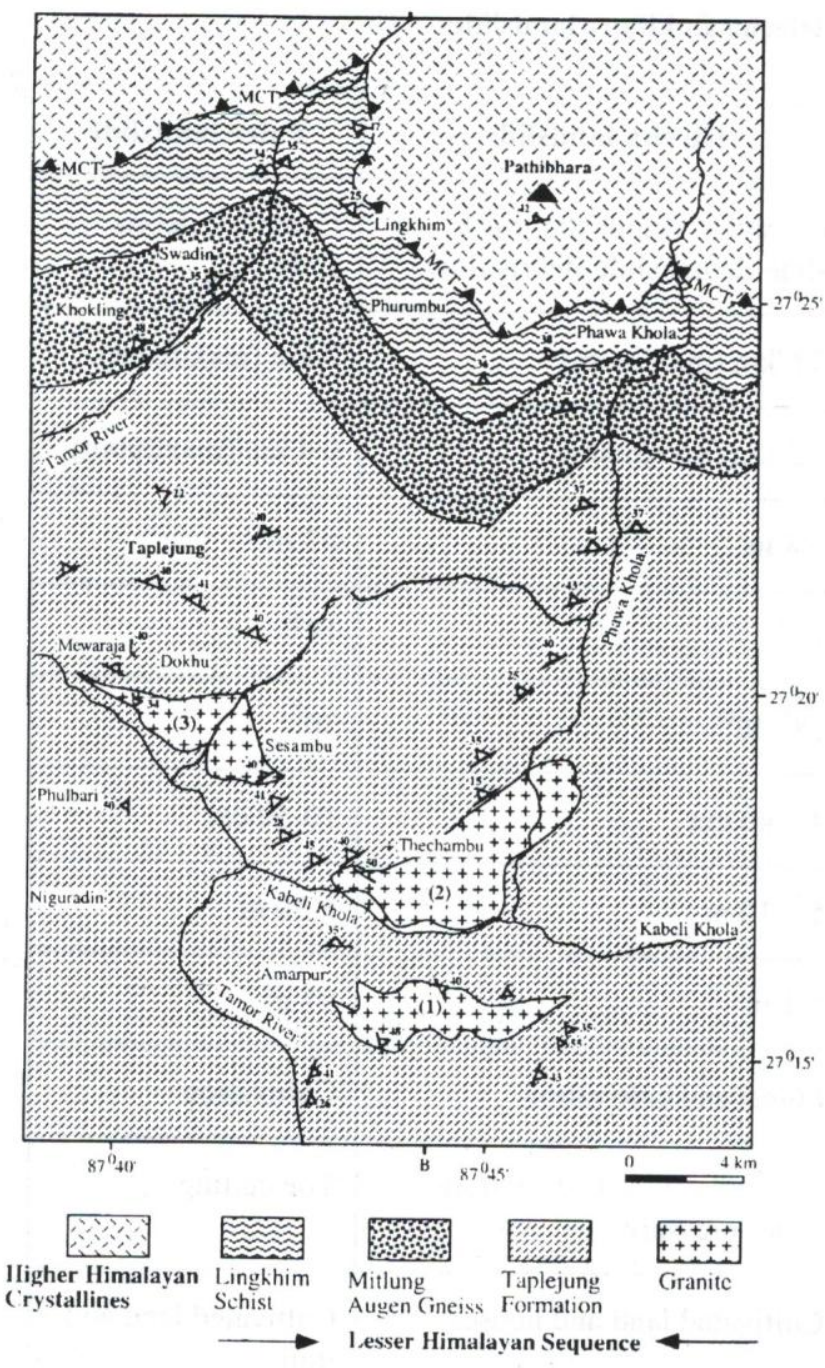

Fig. 2: Geological map of the northern part of Taplejung Window, far eastern Nepal Himalaya (Upreti et al. 2003). MCT: Main Central Thrust, (1) Amarpur granite, (2) Kabeli Khola granite and (3) Tamor River granite.

During the monsoon season, tremendous amount of debris is produced and carried downwards by the Hangdewa Khola. The description of landslide is summarized in Table 1.

\section{Lithology and weathering}

The thick and loose cover of colluvium on the landslide is found to be highly saturated with water near the surface. At the top part of the landslide thick residual soil is formed. The soil belongs to GM to ML according to the Unified Soil Classification System. At the middle part of the landslide, colluvial and residual soil cover the highly weathered phyllitic rocks. The phyllitic rocks are highly susceptible for weathering and production of thick residual soil. The phyllite is arkosic and rich in chlorite and sericite minerals and contains fine clays. The average natural slope of the landslide is $20^{\circ}$ facing towards NW and landslides are most common on slopes between $25^{\circ}$ to $35^{\circ}$.

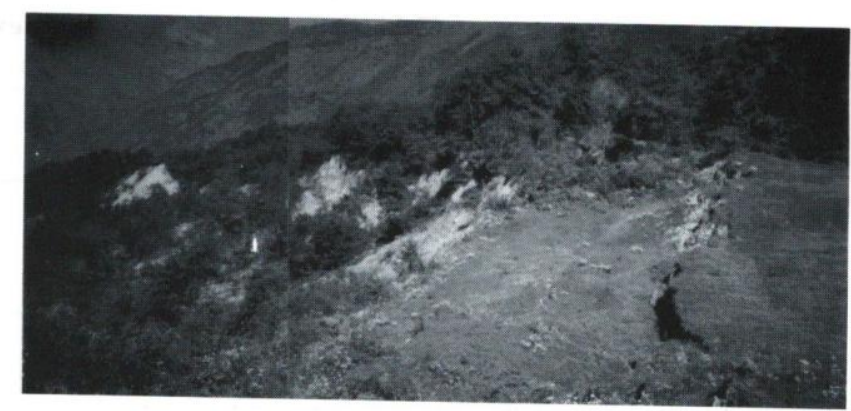

Fig. 3: The crown part of rotational slide occurring in the Hangdewa landslide. View towards north east.

Initially, the mass movement originated along the Hangdewa Khola and later head ward erosion and valley widening developed it into a very large landslide. A diverse and dense network of irrigation system for cardamom farming increased the water saturation on the slope further aggravating the situation of mass movement. Furthermore, the large amount of earth and debris material carried down the slope acts as a triggering agent to the down slope areas.

\section{Hireba landslide}

The northeastern part of the Taplejung Bazaar is already very close to the Hireba landslide and the bazaar may be seriously affected by this landslide in near future. The Hireba Khola is the main drainage outlet of the area. All of the tributaries contributing to Hireba Khola are occupied by the landslide zone. Many old and inactive landslides are found in the area (Fig. 4). The active zone of the landslide is near Hireba, and Siddhigaon villages. The Hangdewa and Hireba landslides have endangered the villages lying between these two landslides. The area of landslide is about $5 \mathrm{sq} \mathrm{km}$ with a length of about $3.6 \mathrm{~km}$ and width of about $1.5 \mathrm{~km}$. This landslide is also at least 100 years old. The main characteristics of the landslide is summarized in Table 1.

\section{Lithology and weathering}

The landlside occurs in the Taplejung Formation having sericite-chlorite-phyllite as the main rock type. A thick residual and colluvial soil is found at the active part of the landslide. A huge amount of earth and debris flows down stream during the monsoon season. The soil on the slope can be classified into $\mathrm{GC}$ and $\mathrm{CL} / \mathrm{CH}$. The Hireba landslide is a combination of a complex landslide. The landslide has the natural slope of $17^{\circ}$ and failed slope of $25-30^{\circ}$. This is a north facing hill slope and the old landslide area before joining the Tamor River on the slope is covered by vegetation. At the toe part, the landslide slope is very gentle

In this area the bedrock is highly weathered and thick clay is formed in many places that creates failure planes. Moreover, clay infiltrates into the pore spaces and fissures, which easily generate the slipping surfaces. Usually, the heavy monsoon commences the failure modes. 
Table 1: Description of Hangdewa, Hireba and Paire landslides

\begin{tabular}{|c|c|c|c|c|}
\hline \multicolumn{2}{|c|}{ Landslide } & Hangdewa landslide & Hireba landslide & Paire landslide \\
\hline \multicolumn{2}{|c|}{ 1. Type of landslide } & $\begin{array}{l}\text { Complex, composite, earth slide- } \\
\text { debris slide-debris flow. }\end{array}$ & $\begin{array}{l}\text { Complex, composite, earth } \\
\text { slide-debris slide-debris flow. }\end{array}$ & $\begin{array}{l}\text { Complex, debris } \\
\text { slide }\end{array}$ \\
\hline \multicolumn{2}{|c|}{ 2. Length } & $5 \mathrm{~km}$ (maximum) & $3.6 \mathrm{~km}$ (maximum) & $2 \mathrm{~km}$ (maximum) \\
\hline \multicolumn{2}{|c|}{ 3. Width } & $2 \mathrm{~km}$ (maximum) & $1.5 \mathrm{~km}$ (maximum) & $0.4 \mathrm{~km}$ (maximum) \\
\hline \multicolumn{2}{|c|}{ 4. Depth } & $>6 \mathrm{~m}$ & $>8 \mathrm{~m}$ & $>3 \mathrm{~m}$ \\
\hline \multicolumn{2}{|c|}{ 5. Natural slope } & $20^{\circ}$ & $17^{0}$ & $19^{0}$ \\
\hline \multicolumn{2}{|c|}{ 6. Failed slope } & $25^{0}-30^{0}$ & $25^{0}-30^{0}$ & $30^{\circ}$ \\
\hline \multirow{3}{*}{ 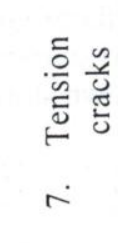 } & Width & $10-50 \mathrm{~cm}$ & $4-40 \mathrm{~cm}$ & $10-50 \mathrm{~cm}$ \\
\hline & Length & $5-40 m$ & $5-10 m$ & $5-30 \mathrm{~m}$ \\
\hline & Depth & $>2 \mathrm{~m}$ & $>1 \mathrm{~m}$ & $>1 \mathrm{~m}$ \\
\hline \multicolumn{2}{|c|}{ 8. Landuse } & Forest and cultivation & Forest and cultivation & Cultivation \\
\hline \multicolumn{2}{|c|}{ 9. Main cause } & $\begin{array}{l}\text { Toe cutting, soil slope and pore } \\
\text { water pressure }\end{array}$ & $\begin{array}{l}\text { Toe cutting, soil slope, pore } \\
\text { water pressure }\end{array}$ & Toe cutting \\
\hline \multicolumn{2}{|c|}{ 10. Damage } & Cultivated land and houses & Cultivated land and houses & $\begin{array}{l}\text { Cultivated land and } \\
\text { trails }\end{array}$ \\
\hline
\end{tabular}

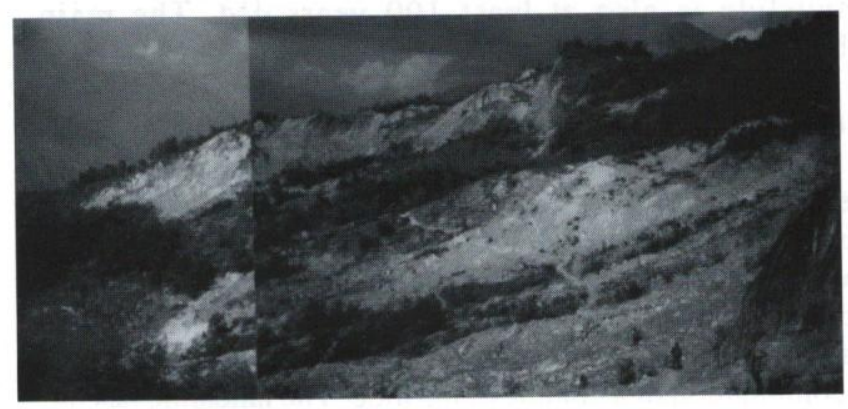

Fig. 4: Eastern part of Hireba landslide. View towards east.

\section{Paire landslide}

This landslide lies on the right bank of Tamor River and on the northern slope of the Phulbari Village. The landslide consists of both active and old mass movement areas. The Paire landslide is one of the active and largest landslides on this slope (Fig. 5).
The landslide started more than seventy years ago. At that time, it covered most of the northern slope of Phulbari Village Development Committee and later on, it became stabilized. After it was naturally stabilized, people again started cultivating the area. The improper agricultural practices caused the reactivation of the old landslide around 14 years ago. The landslide is complex with rotational slide type on the thick colluvium soil cover. The main characteristics of the landslide is summarized in Table 1.

\section{Lithology and weathering}

Highly weathered phyllitic rocks have produced coarsegrained soils of sub-angular to sub-rounded grains and the soil type is GM-ML. The soil depth is more than $15 \mathrm{~m}$ near the failed area. A foot-trail lies near the crown of the landslide. Tension cracks of few $\mathrm{cm}$ to $50 \mathrm{~cm}$ are developed at the crown of the landslide. The deposition of a huge amount of debris from the landslide has made the course of Tamor River to shift towards the opposite bank of the river. The general hill slope angle is $19^{\circ}$ towards northeast 


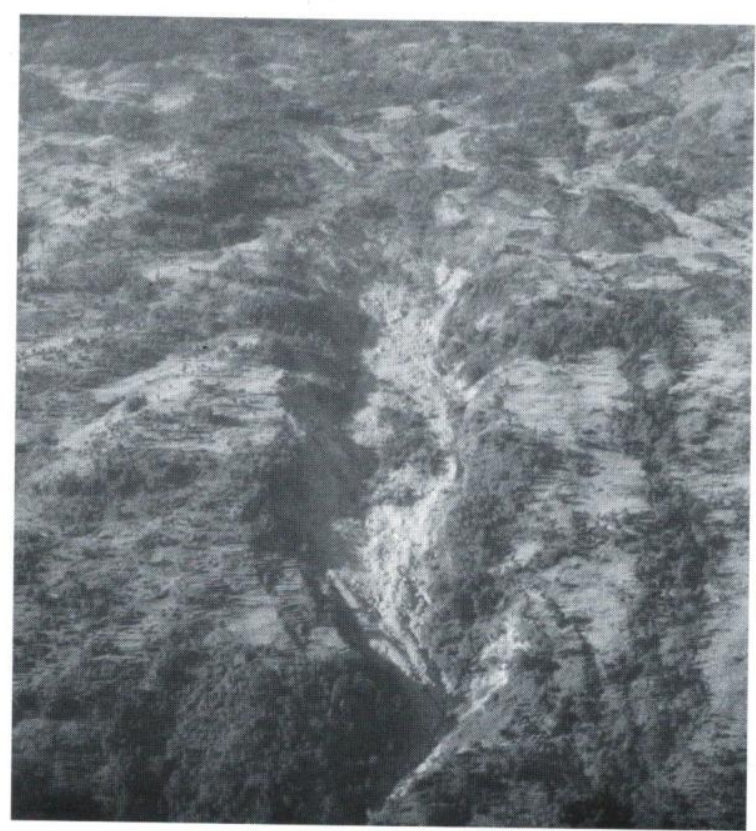

Fig. 5: Paire landslides at Paire village. View towards southwest.

direction. The stepped and converging type of slope curvature exhibits convex nature (Fig. 5).

A number of small tributaries have developed with the main stream, which ultimately drains out to the Tamor River. Many small irrigation canals can be seen in the landslide area. The unplanned agricultural practices and deforestation have aggravated the landslide movement.

\section{ENGINEERING GEOLOGICAL PROPERTIES}

Soil and rock properties were measured and analyzed, and landuse pattern, slope condition, hydrological condition, geological setting and engineering geological characteristics were mapped. Based on these studies an engineering geological map was prepared (Fig. 6).

\section{Lithology}

The phyllite, quartzite, metasandstone and intrusive granitic bodies of the study area have different strength characteristics. The lower part of the Taplejung Formation contains quartzite with higher strength than that of phyllite. The weathering condition also affects the strength. The degree of weathering is generally found to be controlled by frequency of discontinuity and mineralogical composition of rocks.

The phyllite having low persistency has given rise to the highly fractured and fissile nature to the rock. The sandstone bearing phyllite beds have massive rock characteristics and they are quite different rock masses with high strength. The granite exposure along the Mechi Highway between Sesambu to Mewaraja village section is foliated, fractured and highly jointed which has initiated the rock fall. The hill slope is towards west and well-developed three sets of joints are found along this road section, which

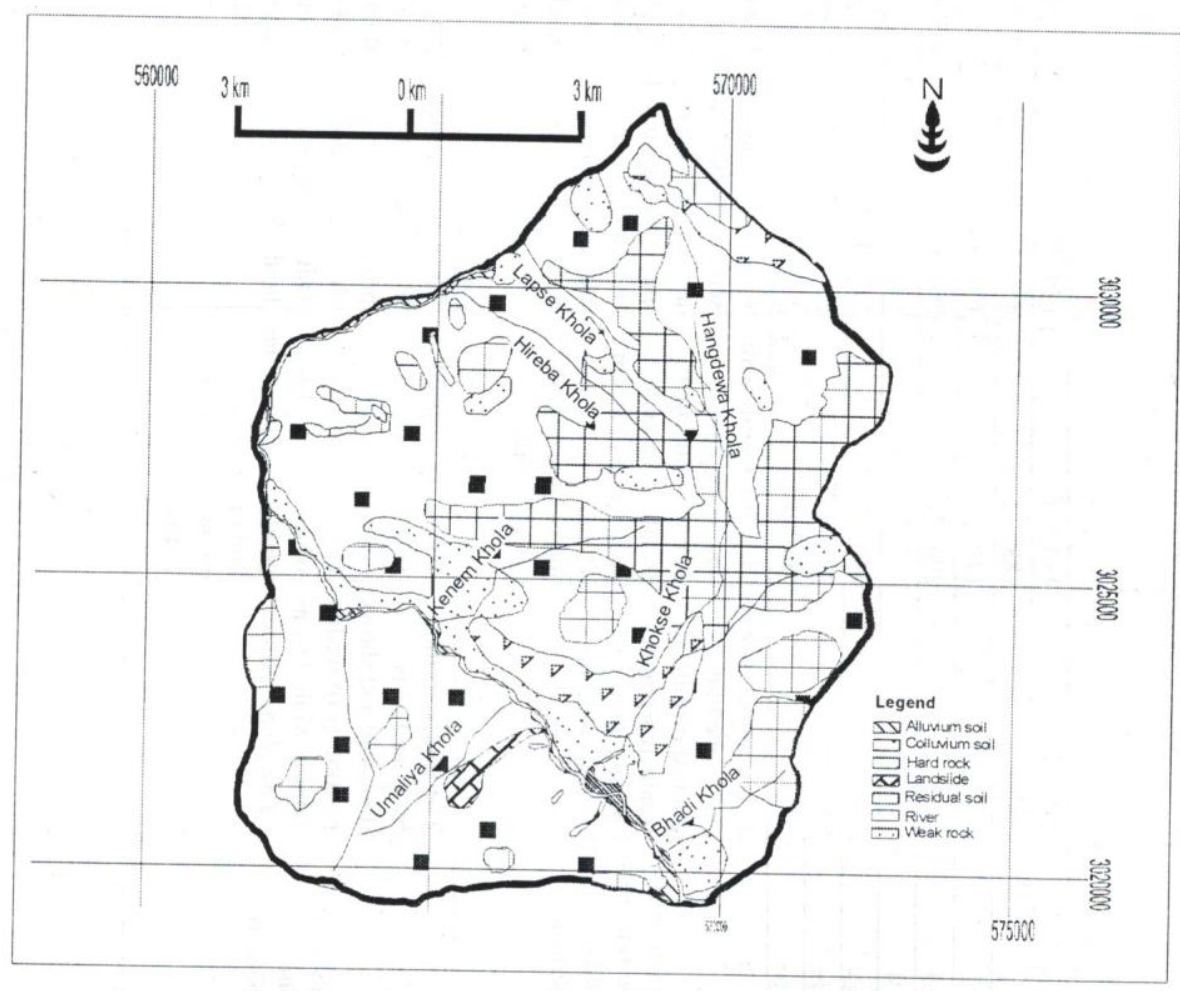

Fig. 6: Engineering geological map of the study area 


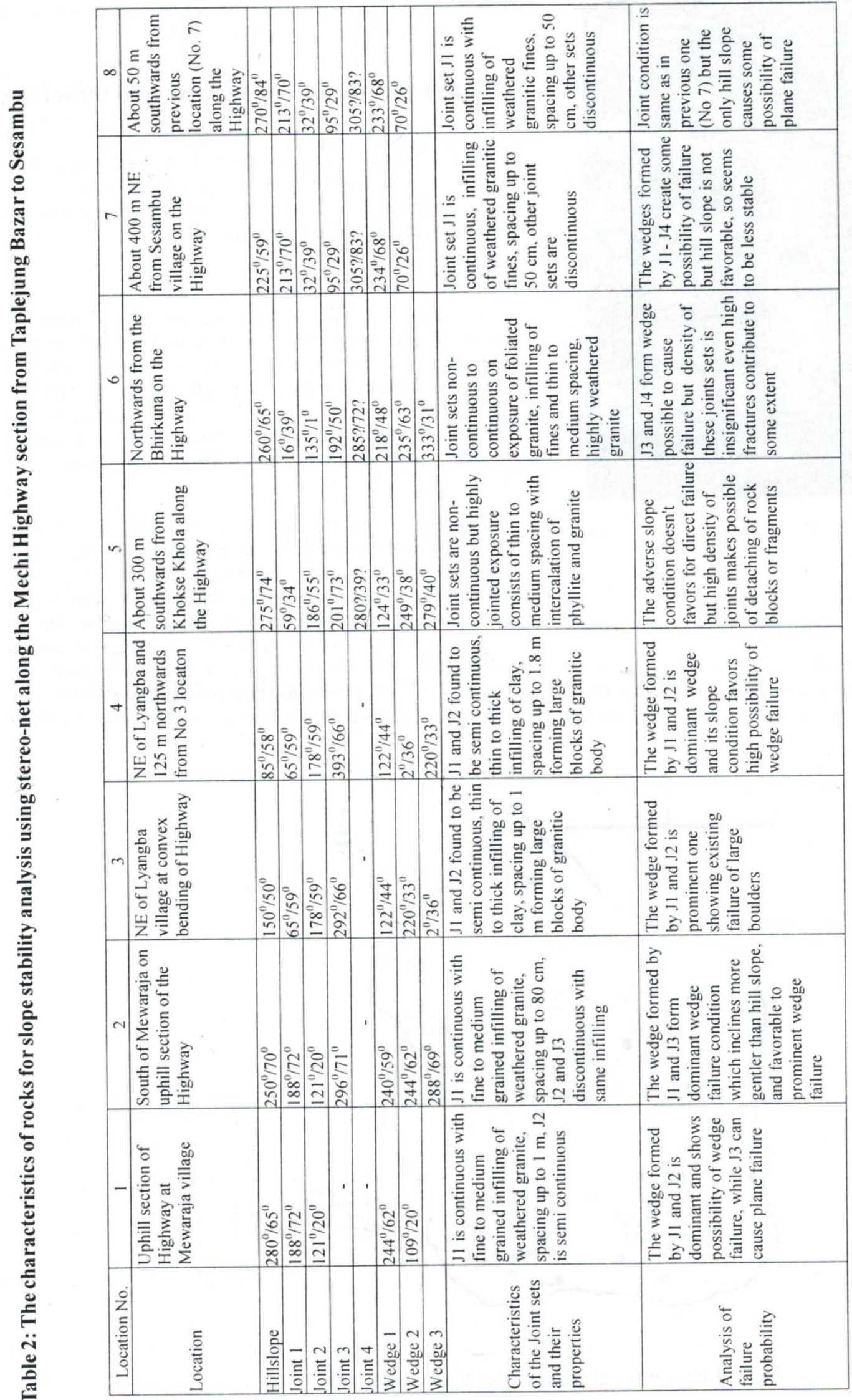


A preliminary engineering geological study in the northern part of the Taplejung Window

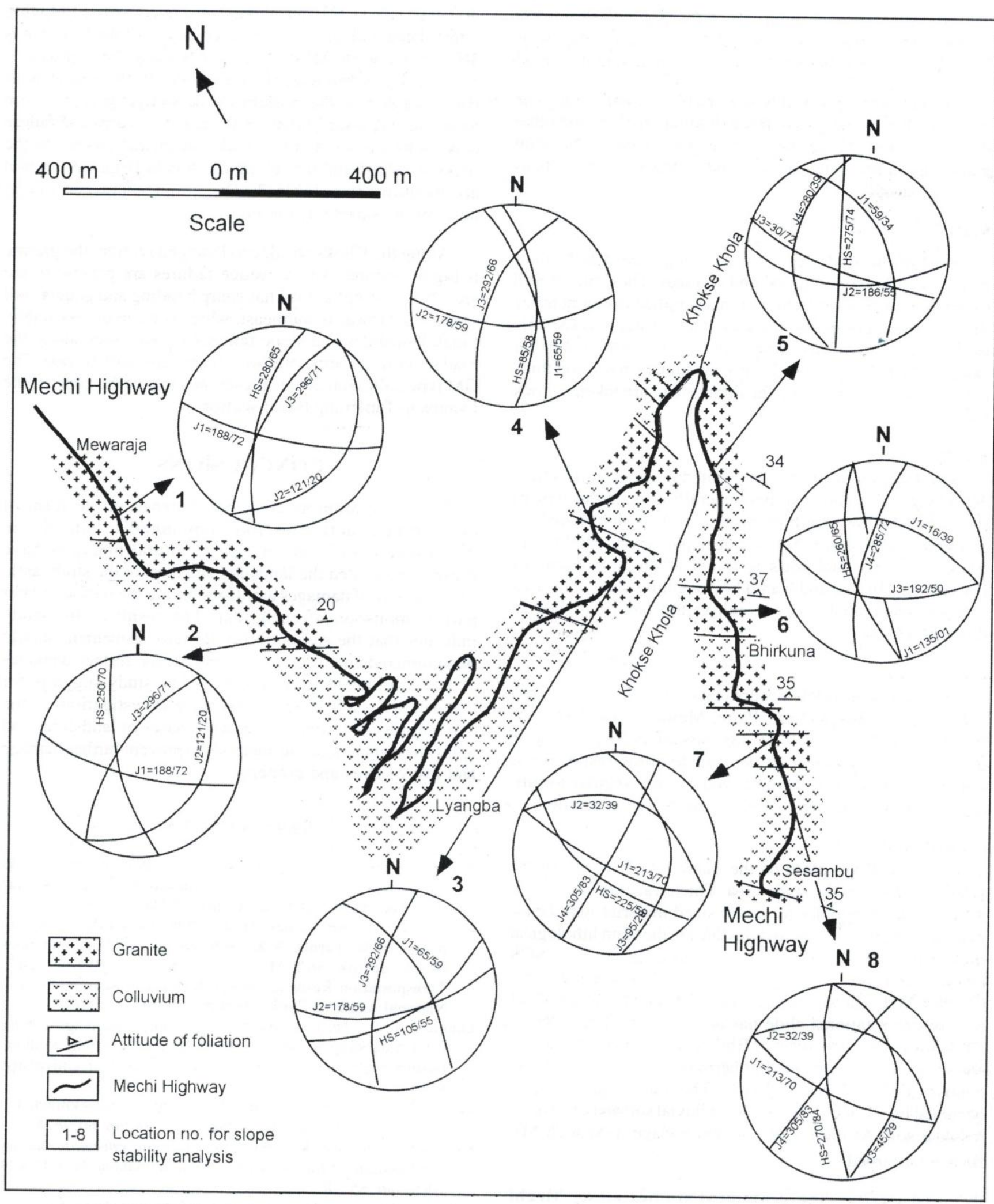

Fig. 7: Engineering geological map of Mechi Highway between Sesambu and Mewaraja 
are the major causes of failure along the highway. Prominent wedge failures also occur in this section of the highway. Rock fall and rockslides are also very common in this area.

The granite is also highly susceptible to weathering. The deep weathering may occur through foliation plane and other discontinuities. Along the road section, most of the joint planes are continuous, smooth and consists of fine silts as infilling material.

\section{Soils}

Soils of the study area are described according to their origin i.e. alluvial, colluvial and residual. The Unified Soil Classification System (USCS) is also applied to characterize the engineering properties of soils. The soil depth is variable in different locations. Therefore, the depth is further categorized to be shallow (1-3 m), medium (3-6 m), and thick $(>6 \mathrm{~m})$. The slopes having the depth $<1 \mathrm{~m}$ are taken as rock slopes.

\section{Residual Soil}

Residual soil is widely distributed on ridges and spurs. The moderate to gentle slopes generally contain this type of soil. The shallow depth of residual soil is distributed on moderate steep slopes below ridges and spurs. Medium to thick cover residual soils is found at the upper part of Hangdewa, Hireba, and Nangkholyang hill slopes. The area is highly vegetated and wet cultivation has flourished in this type of soil.

\section{Colluvial Soil}

Colluvial soil widely occurs in the study area. It is found in Phungling, Bungkulung, Paire, Mewaraja and Chokpur villages. Medium to thick deposits of colluvial soil is distributed at the upper slopes and foothills respectively. The colluvium soil is characterized by very angular to subangular clasts of granite, gneiss, phyllite and quartzite.

\section{Alluvial Soil}

Only the flood plain of the Tamor River contains the alluvial deposit in the study area. The terraces of the Tamor River contains boulder to gravel sized material with fines. Quartzite, granite, gneiss, and phyllite are the main lithological make up of the alluvail soils. According to the USCS classification the colluvial soils can be classified as GM, CL, $\mathrm{CH}$, and $\mathrm{MH}$. The soil to the north of Ajibung village is $\mathrm{CH}$ type where rotational slide has occurred. At the crown of Hangdewa landslide, west of Bhotegaon village $\mathrm{CH}$ type of soil shows high liquid limit. Furthermore, Hangdewa landslide contains GM with ML soil type. The Taplejung Bazaar is occupied by $\mathrm{GC}$ with $\mathrm{CH}$ fines of colluvial soil and CL fine of residual soil. At Paire and Lyangba village, GM with $\mathrm{ML}$ fines is observed.

\section{Detailed engineering geological studies along Mechi Highway between Sesambu and Mewaraja village}

The road section along Mechi Highway from Sesambu to Mewaraja consists of mainly phyllite, metasandstone, quartzite and granite. At Sesambu village, the soil type at downhill side is ML and the uphillside consists of phyllite intercalated with granite. The average dip of the foliation is $35^{\circ}$ towards north. Most of the slopes along the highway is covered by colluvium. The analysis of the joints near Bhirkuna shows the possibility of wedge failure. From Sesambu to Khokse bridge, small erosional scarps and failure conditions are commonly found. The characteristics of the rocks for slope stability along the Mechi Highway section are mentioned in Table 2. The engineering geological description is presented in Fig. 7.

Along the Khokse bridge to Lyangba section, the granite is highly jointed. Active wedge failures are present in the area. Near Lyangba, road has sharp bending and general hill slope is $25^{\circ}$ towards southeast, which is more or less stable. Small landslides and slope failures are also seen along the road section, towards southwest from Taplejung Bazaar. The GM type colluvium soil is present in most of the areas of the Lyanba to Taplejung Bazar section.

\section{CONCLUSIONS}

Excessive anthropogenic interference in the form of development activities like unplanned urbanization, deforestation and unsuitable agricultural practices have greatly aggravated the landslide situation in the study area. The intensity of damages amplifies during the period of later part of monsoon of each year. The result of the study indicates that the susceptibility to mass movement should be minimized and mitigated to prevent the further damages of lives and property in this area. The study suggests for the detailed surface and subsurface investigation of the major landslide to find out the real causes of landslides and apply the right mitigation methods to prevent further damage and loss of lives and property.

\section{REFERENCES}

Bordet, P., 1961, Recherches geologiques dans I'Himalaya du Nepal, region du Makalu. Paris Editions du Centre National de la Recherche Scientifique, Paris, 275 p.

Cruden, D. M. and Varnes, D. J., 1996, Landslide types and processes. In: Turner, A. K., Schuster, R. 1. (Eds.), Landslides Investigation and Mitigation. Special Report 247, Transportation Research Board, National Research Council. National Academy Press, Washington, DC, pp. 36-75.

Gautam, T. P., 2001, Geological mapping and Engineering Geological study in the northern part of the Taplejung Window, Eastern Nepal Himalaya. M. Sc, Thesis, Tribhuvan University, $91 \mathrm{p}$.

Le Fort, P., 1975, Himalaya: The collided range. Present knowledge of the continental arc. Am. J. Sci., v. 275A, pp. 607-628.

Schelling, D. and Arita K., 1991, Thrust tectonic, crustal shortening and structure of the far eastern Nepal Himalaya, Tectonics, $v$ $10(5)$, pp. 851-862.

Schelling, D., 1992, The tectonostratigraphy and structures of the eastern Nepal Himalaya, Tectonics, v. 11(5), pp. 925-943.

Sonyok, D. R., 2001, Geological Studies around Taplejung area, eastern Nepal and landslide hazard mapping of HangdewaHireba watershed. M. Sc, Thesis, Tribhuvan University, 77 p. 
Stocklin, J., 1980, Geology of Nepal and its regional frame. J. Geol. Soc. London, v. 137, pp. 1-34.

Rai, S. M., Upreti, B. N. and Sakai, H., 2001, Geology, structure, and metamorphism of the Taplejung Window and frontal belt, Eastern Nepal (abstract). J. Nepal Geol. Soc., v. 24, pp 26-27.

Rai, S. M., Sakai, H., Upreti, B. N., Takigami, Y., Ghimire, S., Koirala, D. R., Gautam, T. P., Sonyok, D. R. and Poudel, C. P., 2004, Tectonometamorphic evolution of the far-eastern Nepal Himalaya (Abstract). $19^{\text {th }}$ Himalaya-Karakorum-Tibet workshop, Niseko, Japan, v. 2, pp. 225.
Upreti, B. N. and Le Fort, P., 1999, Lesser Himalayn Crystalline nappes of Nepal: Problem of their origin. In: Macfarlane, A., Quade, J., Sorkhabi, R. (Eds.), Geol. Soc. America (Sp. Issue), v. 328 , pp. $225-238$

Upreti, B. N., Sakai, H. and Rai, S. M., 2000. Geology of the Taplejung area (Abstract). Earth Science Frontiers (China University of Earth Sciences, Beijing), v. 7, pp 39-40.

Upreti, B. N., Rai, S. M., Sakai, H., Koirala, D. R. and Takigami, Y., 2003, Early Proterozoic granite of the Taplejung Window, far eastern Lesser Nepal Himalaya. J. Nepal Geol. Soc., v. 28, pp. 9-18. 